\title{
Natural Radioactivity in Miscanthus floridulu Plant from the Uranium Tailing Pile at Guangdong, South China
}

\author{
Gang Song1,2,3*, Qiuping Zhu1,2,3, Minxing Lu1,2,3, Diyun Chen"1,2,3, Yongheng Chen",2,3 \\ ${ }^{1}$ School of Environmental Science \& Engineering, Guangzhou University, Guangzhou, China \\ ${ }^{2}$ Guangdong Province Key Laboratory of Radionuclides Pollution Control and Resources, Guangzhou, China \\ ${ }^{3}$ Key Laboratory of Water Safety \& Protection in the Pearl River Delta, Ministry of Education \& Guangdong \\ Province, Guangzhou, China \\ Email: songg2005@126.com
}

Received 28 May 2014

\section{Abstract}

Large amounts of uranium waste rocks and tailings resulting from the exploitation and treatment of uranium ore at the Northern Guangdong mine (South China) have been accumulated in dams (tailing ponds). To reduce the dispersion of natural radionuclides into the environment, some dams were revegetated with arbor, bush and sward. Besides these plants, Miscanthus floridulu is the dominant plant growing in some of the dams. The uptake and distribution of naturally occurring uranium $\left({ }^{238} \mathrm{U}\right)$, thorium $\left({ }^{232} \mathrm{Th}\right)$, radium $\left({ }^{226} \mathrm{Ra}\right)$ and potassium $\left({ }^{40} \mathrm{~K}\right)$ by Miscanthus floridulu plant from different sample sites of uranium mine were studied under native conditions. The bioconcentration factors (BCFs) of soil to Miscanthus floridulu above-ground and root were calculated and observed to be in the range of 0.14 to 7.74 and 2.71 to 17.83 for ${ }^{238} \mathrm{U}, 0$ to 3.02 and 0 to 3.29 for ${ }^{232} \mathrm{Th}, 0.15$ to 79.76 and 1.01 to 50.22 for ${ }^{226} \mathrm{Ra}$ and 3.00 to 8.41 and 2.69 to 11.22 for ${ }^{40} \mathrm{~K}$, respectively. The transfer factors (TFs) of Miscanthus floridulu root to aboveground were also calculated and observed to be in the range of 0.01 to 0.73 for ${ }^{238} \mathrm{U}, 0$ to 0.99 for ${ }^{232} \mathrm{Th}, 0.08$ to 1.50 for ${ }^{226} \mathrm{Ra}$ and 0.57 to 1.94 for ${ }^{40} \mathrm{~K}$, respectively. The results showed that, Miscanthus floridulu is ${ }^{238} \mathrm{U}$ and ${ }^{226}$ Ra-accumulating plant with significant absorption and accumulation characteristics.

\section{Keywords}

Natural Radionuclides, Uranium Tailings, Miscanthus floridulu, BCFs and TFs

\section{Introduction}

Over the past 50 years, large amounts of uranium waste rocks and tailings resulting from the exploitation and treatment of uranium ore at the Northern Guangdong mine (South China) have been accumulated in dams (tailing ponds). These radioactive solid wastes are exposed in the environment, long-term subjected to wind erosion and rain leaching. The water and soil in the surrounding environment would be polluted with higher ${ }^{238} \mathrm{U},{ }^{226} \mathrm{Ra}$

\footnotetext{
${ }^{*}$ Corresponding author.
}

How to cite this paper: Song, G., Zhu, Q.P., Lu, M.X., Chen, D.Y. and Chen, Y.H. (2014) Natural Radioactivity in Miscanthus floridulu Plant from the Uranium Tailing Pile at Guangdong, South China. Journal of Applied Mathematics and Physics, 2, 848-854. http://dx.doi.org/10.4236/jamp.2014.29095 
and other heavy metals; it will threaten the safety of the local ecological environment.

The traditional method of repair of uranium mine contaminated soil with physical and chemical methods, but it is expensive and requires specialized equipment and technical personnel. Repair is not complete and causes secondary pollution problems. Phytoremediation attracts much attention definitely with low cost and small environmental disturbance.

The study on transfer of natural radionuclides like ${ }^{238} \mathrm{U}$ and ${ }^{232} \mathrm{Th}$ along with their daughter products through the biosphere is important because of their ubiquitous presence and persistence in the environment [1] [2] (Pulhani, 2005; Vinogradov, 1959). These long-lived naturally occurring radionuclides may get transferred to plants along with the nutrients during mineral uptake, accumulate in various parts and even reach the edible portions [1]. Most of the available literature refers to studies of the accumulator plants including Helianthus annuus, Brassica juncea, Lactuca dolichophylla, Cyperus iria L., Miscanthus sinensis and others. However, the accumulator plant's individual short stature, slow growth and small biomass, constitute the bottleneck of application of phytoremediation. The key to break the bottleneck lies in two aspects; first is to improve the bioavailability of radionuclides, and secondly is to improve the plant biomass. The screening of hyperaccumulator is one of important problems that the plant repair technology should solve.

From the practical point of view, short growth cycle and biomass rapid accumulation of herbs have screened quite large value. At home and abroad currently, the enrichment plants and hyperaccumulators for heavy metals mainly are herbaceous plants. The enrichment plants for ${ }^{238} \mathrm{U}$ and ${ }^{226} \mathrm{Ra}$ are mostly economic crops or foods (such as Helianthus annuus [3]-[5], Brassica juncea [6] [7], Lactuca dolichophylla, Cyperus iria L., soybean, etc.). These plants are low biomass, slow growth and longer repair time. The food safety and other defects also decided the limitations of the practical application for these kinds of plants.

The field investigation found that there grows a single, dominant plant species-Miscanthus floridulus-in the uranium mill tailings piles and waste rock heap. It is the Gramineae Miscanthus perennial herbaceous plants, alias $M$. sinensis. It is mainly distributed in tropical Asia. Miscanthus floridulus has the advantages of root system develops, large biomass, fast growth and strong resistance. It often grows in rock crevices and gravel pile. It also can closure rain, conserve water and prevent the topsoil runoff and landslides and has very high value of water and soil conservation. Therefore, the main goal of this study was to evaluate ${ }^{238} \mathrm{U},{ }^{232} \mathrm{Th},{ }^{226} \mathrm{Ra}$ and ${ }^{40} \mathrm{~K}$ uptake and distribution from uranium mill tailings by quantifying the total and available fraction of radionuclides in the solid wastes and to estimate its transfer to plants growing on the tailing piles. Gamma spectrometry was used to estimate ${ }^{238} \mathrm{U},{ }^{232} \mathrm{Th},{ }^{226} \mathrm{Ra}$ and ${ }^{40} \mathrm{~K}$ concentrations in soil, solid waste and plant.

\section{Materials and Methods}

\subsection{The Study Area and Sampling Location}

The Northern Guangdong uranium mine is located in the north of Guangdong province near Jiangxi province, South China. The mine's exploitation began in 1950s for uranium extraction. At present, uranium mine continues to production, but the extensive exploitation and treatment of the uranium ore in this mine, has led to an accumulation of large amounts of solid wastes (tailings). The solid wastes are composed mainly of tails and silt particles that resulted from sulphuric acid-leaching of uranium, after ore crushing and grinding. The aqueous phase containing the chemical components resulting from solvent extraction and/or ion-exchange separation to concentrate uranium from the leaching solution is also deposited at the dams. Thus, the chemical composition is complex and variable, depending not only on the nature of the original ore and added milling reagents, but also on climatic conditions and on weathering reactions that occurred following the disposal.

\subsection{Sample Collection and Processing}

Miscanthus floridulus and tailing (solid waste) samples from the soil within the rooting zone of the plants were collected from uranium tailing piles in the above mentioned sample sites between May 2010 and December 2011. Reference samples of plants and soils were also collected from areas within $0.5 \mathrm{~km}$ of the tailing piles.

Plants were harvested and washed to remove adhering soil particles. Roots were separated from the aboveground parts of the plants, air-dried and weighed. They were then dried at $110^{\circ} \mathrm{C}$ until the weight was constant, cooled and weighed again. The dried samples were ashed at $550^{\circ} \mathrm{C}$ for $8 \mathrm{~h}$ (or until they formed a white ash) in a muffle furnace, cooled and weighed. 
Tailings and soil reference samples were collected from the rooting zone of the plants. They were homogenised to obtain a representative sample. The tailing and soil samples were dried at room temperature and the fraction less than $\leq 0.25 \mathrm{~mm}$ was retained for analysis.

Tailings (about $300 \mathrm{~g}$ ), soil (about $250 \mathrm{~g}$ ) and ashed plant (aerial parts about $30 \mathrm{~g}$ and roots about $40 \mathrm{~g}$ ) samples were counted for 4 (tailings and soils) and 24 (plants) hours in sealed containers (70 mm $\times 75 \mathrm{~mm}$ ), after one month's delay to allow equilibrium of ${ }^{226} \mathrm{Ra}$ with its short-lived daughters.

\subsection{Radioactivity Measurement}

The activity concentrations of the natural radionuclides ${ }^{238} \mathrm{U},{ }^{226} \mathrm{Ra},{ }^{232} \mathrm{Th}$ and ${ }^{40} \mathrm{~K}$ were determined in tailings, soil and plant samples by gamma-spectrometry using a Canberra HPGe detector, with a relative efficiency of $30 \%$ and an energy resolution of $1.8 \mathrm{keV}$ for ${ }^{60} \mathrm{Co} \gamma$-ray energy line at $1332 \mathrm{keV}$, with $3800 \mathrm{~mm}^{2}$ active area and 70 $\mathrm{mm}^{2}$ active diameter [8].

\subsection{Data Processing and Analysis}

A common approach to quantifying the availability of soil radionuclides for plant uptake is the ratio between plant activity concentration $\left(\mathrm{Bq} \cdot \mathrm{kg}^{-1}\right)$ and total soil activity concentration $\left(\mathrm{Bq} \cdot \mathrm{kg}^{-1}\right)$, usually termed as bioconcentration factors $\left(\mathrm{BCFs}=\right.$ activity concentration of radionuclides in plants $\mathrm{Bq} \cdot \mathrm{kg}^{-1}$ dry weight/ activity concentration of radionuclides in soil $\mathrm{Bq} \cdot \mathrm{kg}^{-1}$ dry weight) and transfer factors (TFs = activity concentration of radionuclides in aboveground parts of plants $\mathrm{Bq} \cdot \mathrm{kg}^{-1}$ dry weight/ activity concentration of radionuclides in roots of plants $\mathrm{Bq} \cdot \mathrm{kg}^{-1}$ dry weight).

\section{Results and Discussion}

The uptake and distribution of naturally occurring uranium $\left({ }^{238} \mathrm{U}\right)$, thorium $\left({ }^{232} \mathrm{Th}\right)$, radium $\left({ }^{226} \mathrm{Ra}\right)$ and potassium $\left({ }^{40} \mathrm{~K}\right)$ by Miscanthus floridulu plant from different sample sites of uranium mine were studied under native conditions.

\subsection{Natural Radioactivity in Root Soils}

Table 1 gives the concentration of ${ }^{238} \mathrm{U},{ }^{232} \mathrm{Th},{ }^{226} \mathrm{Ra}$ and ${ }^{40} \mathrm{~K}$ in the root soils collected from all the fields. The

Table 1. Activity concentrations of ${ }^{238} \mathrm{U},{ }^{232} \mathrm{Th},{ }^{226} \mathrm{Ra}$ and ${ }^{40} \mathrm{~K}$ in the root soils $\left(\mathrm{Bq} \cdot \mathrm{kg}^{-1}\right)$.

\begin{tabular}{|c|c|c|c|c|}
\hline Samples & ${ }^{238} \mathrm{U}$ & ${ }^{226} \mathrm{Ra}$ & ${ }^{232} \mathrm{Th}$ & ${ }^{40} \mathrm{~K}$ \\
\hline S1 & 20338.2 & 16235.2 & 184.3 & 1357.2 \\
\hline S2 & 8127.5 & 3022.7 & 84.8 & 1757.0 \\
\hline S3 & 2938.3 & 1048.6 & 123.5 & 2629.5 \\
\hline S4 & 11719.2 & 950.7 & 84.3 & 1523.8 \\
\hline S5 & 187917.0 & 176007.0 & 248.1 & 1857.5 \\
\hline S6 & 39064.3 & 103375.3 & 414.2 & 1252.9 \\
\hline S7 & 50010.2 & 175620.7 & 95.3 & 1089.5 \\
\hline S8 & 29615.6 & 102558.4 & 114.6 & 1423.3 \\
\hline S9 & 74171.1 & 263621.9 & 117.8 & 1974.0 \\
\hline S10 & 30215.2 & 110054.7 & 121.8 & 1503.6 \\
\hline S11 & 1073.2 & 4253.5 & 274.4 & 986.5 \\
\hline S12 & 1154.5 & 3087.1 & 298.0 & 1400.4 \\
\hline S13 & 2529.9 & 1304.7 & 198.0 & 1654.4 \\
\hline S14 & 4519.6 & 3244.1 & 106.3 & 1277.8 \\
\hline S15 & 157.3 & 132.6 & 96.7 & 830.7 \\
\hline S16 & 153.0 & 99.8 & 86.6 & 660.9 \\
\hline S17 & 163.2 & 90.8 & 99.2 & 666.6 \\
\hline
\end{tabular}


radionuclide contents of the different root soils are showing regional variations and strong dependence on their geological precursor or the parent rock during its genesis. There were higher ${ }^{238} \mathrm{U}$ and ${ }^{226} \mathrm{Ra}$ contents in the root soils from the tailing ponds

\subsection{Natural Radioactivity Distribution in Different Parts of the Miscanthus floridulus}

In order to study the translocation and preferred site of accumulation of a radionuclide the total content of a radionuclide in whole plant has been normalized for fresh weight fraction of each plant part. The percent distributions of the radionuclides in various parts of the Miscanthus floridulus are shown in Table 2.

The distribution of ${ }^{238} \mathrm{U},{ }^{232} \mathrm{Th},{ }^{226} \mathrm{Ra}$ and ${ }^{40} \mathrm{~K}$ in different parts of the Miscanthus floridulus showed the decreasing trend as root $>$ aboveground.

\subsection{Transfer Factors (TFs) and Bioconcentration Factors (BCFs) for Natural Radioactivity}

Transfer factors (TFs) were calculated as the ratio of the radionuclide concentration in plant aboveground (Bq $\cdot \mathrm{kg}^{-1}$ plant) to its concentration in root (Bq/kg root). And bioconcentration factors (BCFs) were calculated as the ratio of the radionuclide concentration in root $\left(\mathrm{Bq} \cdot \mathrm{kg}^{-1}\right.$ root) to its concentration in soil $(\mathrm{Bq} / \mathrm{kg}$ soil). The calculated results are given in Table 3 and Table 4.

The bioconcentration factors (BCFs) of soil to Miscanthus floridulu aboveground and root were calculated and observed to be in the range of 0.06 to $8.95(1.77 \pm 2.63)$ and 0.22 to $19.60(6.96 \pm 6.06)$ for ${ }^{238} \mathrm{U}, 0.13$ to $4.89(1.72 \pm 1.42)$ and 0.48 to $6.41(2.55 \pm 1.61)$ for ${ }^{232} \mathrm{Th}, 0.15$ to $43.87(8.44 \pm 13.86)$ and 0.45 to 103.94 (20.50 \pm 29.18$)$ for ${ }^{226} \mathrm{Ra}$ and 1.66 to $28.99(6.72 \pm 6.29)$ and 2.67 to $35.79(10.59 \pm 8.77)$ for ${ }^{40} \mathrm{~K}$, respectively.

Table 2. ${ }^{238} \mathrm{U},{ }^{232} \mathrm{Th},{ }^{226} \mathrm{Ra}$ and ${ }^{40} \mathrm{~K}$ distribution in the roots and abovegrounds (fresh) of Miscanthus floridulus.

\begin{tabular}{|c|c|c|c|c|c|c|c|c|}
\hline \multirow{2}{*}{ Samples } & \multicolumn{2}{|c|}{${ }^{238} \mathrm{U}\left(\mathrm{Bq} \cdot \mathrm{kg}^{-1}\right)$} & \multicolumn{2}{|c|}{${ }^{226} \mathrm{Ra}\left(\mathrm{Bq} \cdot \mathrm{kg}^{-1}\right)$} & \multicolumn{2}{|c|}{${ }^{232} \mathrm{Th}\left(\mathrm{Bq} \cdot \mathrm{kg}^{-1}\right)$} & \multicolumn{2}{|c|}{${ }^{40} \mathrm{~K}\left(\mathrm{~Bq} \cdot \mathrm{kg}^{-1}\right)$} \\
\hline & Root & $\mathrm{AG}$ & Root & $\mathrm{AG}$ & Root & $\mathrm{AG}$ & Root & $\mathrm{AG}$ \\
\hline $\mathrm{S} 1$ & 83270.5 & 2868.6 & 29864.5 & 2440.1 & 130.2 & 23.2 & 15226.3 & 9890.6 \\
\hline $\mathrm{S} 2$ & 35019.1 & 3852.3 & 17595.2 & 6736.9 & 121.4 & 49.4 & 13487.0 & 8580.1 \\
\hline S3 & 29445.1 & 1359.7 & 5715.5 & 2290.8 & 357.4 & 94.6 & 11397.8 & 8654.1 \\
\hline S4 & 4278.0 & 1436.3 & 98819.0 & 16834.5 & 40.7 & 29.5 & 54530.0 & 4696.8 \\
\hline S5 & 41252.2 & 13645.1 & 79705.4 & 46965.1 & 872.3 & 591.8 & 7665.2 & 7165.7 \\
\hline S6 & 318591.0 & 18513.4 & 280150.3 & 47635.1 & 268.7 & 74.0 & 8925.4 & 4205.4 \\
\hline S7 & 135542.5 & 24933.0 & 177146.9 & 78166.3 & 610.4 & 268.3 & 5271.5 & 3271.0 \\
\hline S8 & 52776.7 & 7440.3 & 178888.7 & 26623.0 & 522.7 & 248.6 & 3830.8 & 7424.3 \\
\hline S9 & 92698.5 & 4418.1 & 251794.6 & 78166.3 & 365.7 & 130.4 & 5271.5 & 3271.0 \\
\hline S10 & 225034.1 & 56276.3 & 1842979.7 & 265637.4 & 459.2 & 182.4 & 5970.3 & 4913.1 \\
\hline S11 & 5659.8 & 4135.4 & 6656.4 & 10571.9 & 812.6 & 744.9 & 9693.8 & 9410.8 \\
\hline $\mathrm{S} 12$ & 14821.8 & 388.8 & 99142.9 & 1480.2 & 167.6 & 40.7 & 36955.2 & 7297.1 \\
\hline S13 & 8175.4 & 3024.1 & 24910.2 & 8853.2 & 558.0 & 310.2 & 24114.1 & 14812.6 \\
\hline S14 & 19140.6 & 1558.9 & 10917.7 & 4203.3 & 124.4 & 123.5 & 11855.7 & 6767.9 \\
\hline S15 & 2498.7 & 671.8 & 4242.2 & 3508.2 & 282.9 & 414.3 & 12946.4 & 24082.2 \\
\hline S16 & 2999.4 & 1023.5 & 6107.3 & 4378.6 & 301.4 & 423.7 & 6780.3 & 7246.4 \\
\hline $\mathrm{S} 17$ & 2747.9 & 1460.7 & 5319.5 & 3244.1 & 190.0 & 247.1 & 6504.2 & 4205.1 \\
\hline
\end{tabular}

Note: AG-Above ground. 
Table 3. Calculated BCFs for the roots and abovegrounds of Miscanthus floridulus.

\begin{tabular}{|c|c|c|c|c|c|c|c|c|}
\hline \multirow[b]{3}{*}{ Samples } & \multicolumn{8}{|c|}{ BCFs } \\
\hline & \multicolumn{2}{|c|}{${ }^{238} \mathrm{U}$} & \multicolumn{2}{|c|}{${ }^{226} \mathrm{Ra}$} & \multicolumn{2}{|c|}{${ }^{232} \mathrm{Th}$} & \multicolumn{2}{|c|}{${ }^{40} \mathrm{~K}$} \\
\hline & Root & $\mathrm{AG}^{1}$ & Root & AG & Root & AG & Root & AG \\
\hline S1 & 4.09 & 0.14 & 1.84 & 0.15 & 0.71 & 0.13 & 11.22 & 7.29 \\
\hline S2 & 4.31 & 0.47 & 5.82 & 2.23 & 1.43 & 0.58 & 7.68 & 4.88 \\
\hline S3 & 10.02 & 0.46 & 5.45 & 2.18 & 2.89 & 0.77 & 4.33 & 3.29 \\
\hline S4 & 0.37 & 0.12 & 103.94 & 17.71 & 0.48 & 0.35 & 35.79 & 3.08 \\
\hline S5 & 0.22 & 0.07 & 0.45 & 0.27 & 3.52 & 2.39 & 4.13 & 3.86 \\
\hline S6 & 8.16 & 0.47 & 2.71 & 0.46 & 0.65 & 0.18 & 7.12 & 3.36 \\
\hline S7 & 2.71 & 0.50 & 1.01 & 0.45 & 6.41 & 2.82 & 4.84 & 3.00 \\
\hline S8 & 1.78 & 0.25 & 1.74 & 0.26 & 4.56 & 2.17 & 2.69 & 5.22 \\
\hline S9 & 1.25 & 0.06 & 0.96 & 0.30 & 3.10 & 1.11 & 2.67 & 1.66 \\
\hline S10 & 7.45 & 1.86 & 16.75 & 2.41 & 3.77 & 1.50 & 3.97 & 3.27 \\
\hline S11 & 5.27 & 3.85 & 1.56 & 2.49 & 2.96 & 2.71 & 9.83 & 9.54 \\
\hline S12 & 12.84 & 0.34 & 32.12 & 0.48 & 0.56 & 0.14 & 26.39 & 5.21 \\
\hline S13 & 3.23 & 1.20 & 19.09 & 6.79 & 2.82 & 1.57 & 14.58 & 8.95 \\
\hline S14 & 4.24 & 0.34 & 3.37 & 1.30 & 1.17 & 1.16 & 9.28 & 5.30 \\
\hline S15 & 15.88 & 4.27 & 31.99 & 26.46 & 2.93 & 4.28 & 15.58 & 28.99 \\
\hline S16 & 19.60 & 6.69 & 61.20 & 43.87 & 3.48 & 4.89 & 10.26 & 10.96 \\
\hline S17 & 16.84 & 8.95 & 58.58 & 35.73 & 1.92 & 2.49 & 9.76 & 6.31 \\
\hline
\end{tabular}

Table 4. Calculated TFs for the roots and abovegrounds of Miscanthus floridulus.

\begin{tabular}{lllll}
\hline & & & & \\
Samples & ${ }^{238} \mathrm{U}$ & ${ }^{226} \mathrm{Ra}$ & ${ }^{40} \mathrm{~K}$ \\
\hline S1 & 0.08 & 0.18 & 0.65 & 2.37 \\
S2 & 0.38 & 0.41 & 0.64 & 3.48 \\
S3 & 0.40 & 0.26 & 0.76 & 0.58 \\
S4 & 0.17 & 0.72 & 0.09 & 1.78 \\
S5 & 0.59 & 0.68 & 0.93 & 2.93 \\
S6 & 0.17 & 0.28 & 0.47 & 2.40 \\
S7 & 0.44 & 0.44 & 0.62 & 1.06 \\
S8 & 0.15 & 0.48 & 1.94 & 6.51 \\
S9 & 0.31 & 0.36 & 0.62 & 0.58 \\
S10 & 0.14 & 0.40 & 0.82 & 2.17 \\
S11 & 1.59 & 0.92 & 0.97 & 0.57 \\
S12 & 0.01 & 0.24 & 0.20 & 0.96 \\
S13 & 0.36 & 0.56 & 0.61 & 4.15 \\
S14 & 0.38 & 0.99 & 0.57 & 3.08 \\
S15 & 0.83 & 1.46 & 1.86 & 2.10 \\
S16 & 0.72 & 1.41 & 0.65 &
\end{tabular}


The transfer factors (TFs) of Miscanthus floridulu root to aboveground were also calculated and observed to be in the range of 0.03 to $0.73(0.23 \pm 0.20)$ for ${ }^{238} \mathrm{U}, 0.18$ to $1.46(0.65 \pm 0.42)$ for ${ }^{232} \mathrm{Th}, 0.01$ to $1.59(0.43 \pm$ $0.37)$ for ${ }^{226} \mathrm{Ra}$ and 0.09 to $1.94(0.79 \pm 0.48)$ for ${ }^{40} \mathrm{~K}$, respectively. A major average percentage of total $83 \%$ (57\% - 97\%) for ${ }^{238} \mathrm{U}, 64 \%\left(40 \%\right.$ - 85\%) for ${ }^{232} \mathrm{Th}$ and $73 \%(39 \%-98 \%)$ for ${ }^{226} \mathrm{Ra}$ activity in the plant is concentrated in the roots, and only about $17 \%(2.6 \%-42 \%)$ for ${ }^{238} \mathrm{U}$, 36\% $(15 \%-49 \%)$ for ${ }^{232} \mathrm{Th}$ and $27 \%(1.5 \%$ $61 \%$ ) for ${ }^{226} \mathrm{Ra}$ was distributed in the aboveground, whereas about $59 \%$ of ${ }^{40} \mathrm{~K}$ activity accumulated in the roots and $41 \%$ in the aboveground. The results showed that, Miscanthus floridulu is ${ }^{238} \mathrm{U}$ and ${ }^{226} \mathrm{Ra}$-accumulating plant with significant absorption and accumulation characteristics, but their BCFs and TFs are not in accord with traditional hyperaccumulator definition.

The nearly comparable value of transfer factors for radionuclides in spite of their different concentration levels in soil is a result of very complex behavior of elements in soil. Yunoki [9] have reported that the degrees of accumulation of natural radioactive elements are affected by the metal-selective function of plants during uptake of elements so as to maintain the mechanism of homeostasis in normal environment.

\section{Conclusions}

The soils show characteristics of the pollution from the uranium waste rocks and tailings, with regards to their radionuclide contents. The uptake of uranium, thorium and radium appears to be regulated by the requirement of the Miscanthus floridulu for essential nutrients. Radium uptake by Miscanthus floridulu is more than uranium for the soils polluted by the uranium waste rocks and tailings. Under natural field conditions, the concentration of a radionuclide in the receptor compartment (root or aboveground) changed with the concentration in the source compartment (soil) is high or low.

To reduce the dispersion of natural radionuclides into the environment, some uranium tailings dams were revegetated with arbor, bush and sward. Besides these plants, Miscanthus floridulus is the dominant plant growing in some of the dams. The results showed that, Miscanthus floridulu is ${ }^{238} \mathrm{U}$ and ${ }^{226} \mathrm{Ra}$-accumulating plant with significant absorption and accumulation characteristics, but their BCFs and TFs are not in accord with traditional hyperaccumulator definition. Even the BCFs and TFs of some plants do not reach a certain threshold, but their large biomass also can make them a hyperaccumulator. Miscanthus floridulus has outstanding characteristics of fast growth and large biomass; it will provide us a new plant material to study hyperaccumulator selection and phytoremediation engineering in uranium tailings environment.

\section{Acknowledgements}

Supports by the National Natural Science Foundation of China (No.41373117, 40930743) are gratefully acknowledged.

\section{References}

[1] Pulhani, V.A., Dafauti, S., Hegde, A.G., Sharma, R.M. and Mishra, U.C. (2005) Uptake and Distribution of Natural Radioactivity in Wheat Plants from Soil. Journal of Environmental Radioactivity, 79, 331-346. http://dx.doi.org/10.1016/j.jenvrad.2004.08.007

[2] Vinogradov, A.P. (1959) The Geochemistry of Rare and Dispersed Chemical Elements in Soils. 2nd Edition, Consultants Bureau, New York.

[3] Chen, Y. and Cutright, T. (2001) EDTA and HEDTA Effects on Cd, Cr, and Ni Uptake by Helianthus annuus. Chemosphere, 45, 21-28. http://dx.doi.org/10.1016/S0045-6535(01)00031-5

[4] Meers, E., Ruttens, A., Hopgood, M.J., Samson, D. and Tack, F.M.G. (2005) Comparison of EDTA and EDDS as Potential Soil Amendments for Enhanced Phytoextraction of Heavy Metals. Chemosphere, 58, 1011-1022. http://dx.doi.org/10.1016/j.chemosphere.2004.09.047

[5] Blanco Rodríguez, P., Vera Tomé, F., Pérez Fernaández, M. and Lozano, J.C. (2006) Linearity Assumption in Soil-toPlant Transfer Factors of Natural Uranium and Radium in Helianthus annuus L. Science of the Total Environment, 361, 1-7. http://dx.doi.org/10.1016/j.scitotenv.2005.08.020

[6] Prasad, M.N.V. and Freitas, H.M.O. (2003) Metal Hyperaccumulation in Plants Biodiversity Prospecting for Phytoremediation Technology. Electronic Journal of Biotechnology, 6, 285-321. http://dx.doi.org/10.2225/vol6-issue3-fulltext-6

[7] Huang, J.W., Blaylock, M.J., Kapulnik, Y. and Ensley, B.D. (1998) Phytoremediation of Uranium-Contaminated Soils: 
Role of Organic Acids in Triggering Uranium Hyperaccumulation in Plants. Environmental Science Technology, 32, 2004-2008. http://dx.doi.org/10.1021/es971027u

[8] Song, G., Chen, D.Y., Zhang, Z.Q. and Xie, W.B. (2012) Natural Radioactivity Levels in Topsoil from the Pearl River Delta Zone, Guangdong, China. Journal of Environmental Radioactivity, 103, 48-53.

http://dx.doi.org/10.1016/j.jenvrad.2011.06.014

[9] Yunoki, E., Katoaka, T., Michiro, K., Sugiyama, H., Shimizu, M. and Mori, T. (1993) Activity Concentrations of ${ }^{238} \mathrm{U}$ and ${ }^{226} \mathrm{Ra}$ in Agricultural Samples. Journal of Radio Analytical Nuclear Chemistry Articles, 174, 223-228.

http://dx.doi.org/10.1007/BF02037909 